\title{
DAMPAK PENGOLAHAN DAN KONSUMSI SUP SIRIP IKAN HIU
}

\section{Impact Of Shark Fish Sirip Processing And Consumption}

\author{
Firda Yusrina ${ }^{1}$, Vika Milatil Atkhiyah ${ }^{2}$, Isah Afkarina ${ }^{3}$ \\ ${ }^{1}$ Mahasiswa Pascasarjana Universitas Brawijaya Malang \\ ${ }^{2,3}$ Mahasiswa Program Studi Teknologi Hasil Pertanian Universitas Wiraraja Sumenep \\ J1 Raya Sumenep Pamekasan Km 5 Patean Sumenep; firdayusrina95@ gmail.com
}

\begin{abstract}
ABSTRAK
Indonesia adalah negara kepulauan yang terdiri dari $2 / 3$ lautan dan $1 / 3$ daratan. Lautan teritorial yang luas tentu memiliki banyak keanekaragaman kehidupan laut. Salah satunya adalah hiu. Ada 25 jenis hiu di oncean indonesia. Akhir-akhir ini hiu telah menjadi salah satu topik yang dibahas dalam lembaga perikanan dan aktivis fauna, karena meningkatnya aktivitas berburu hiu. Sirip hiu sedang memotong sirip hiu dan melemparkan sisa-sisa tubuh yang masih hidup, sering dengan membuangnya kembali ke laut. Hiu tubuh tanpa sirip sering dibuang kembali ke laut hidup-hidup, di mana mereka mati karena tidak dapat berenang benar dan berdarah banyak atau mati karena kehilangan darah. Sirip hiu adalah target yang menggoda bagi para nelayan karena mereka memiliki nilai moneter dan budaya yang tinggi. Sirip digunakan dalam hidangan populer yang disebut sup sirip hiu, yang merupakan simbol status. Ulasan ini akan memberikan deskripsi tentang definisi sirip hiu, sup sirip hiu, kelezatan dengerous untuk manusia dan hiu sama-sama dan bertujuan untuk melindungi populasi hiu.
\end{abstract}

Kata kunci: lautan Indonesia; Selamatkan hiu kami; Financing Hiu; Sup sirip hiu.

\section{ABSTRACT}

Indonesia is an archipelagic country that consist of $2 / 3$ ocean and $1 / 3$ land. The extensive territorial ocean is certainly have a lot of diversity of marine existence. One of them is shark. There are 25 kinds of sharks in indonesian's oncean. Lately sharks have become one of the topics discussed in fisheries institutions and fauna activists, due to the increasing activity of hunting shark. Shark finning is cutting off a shark's fin and throwing the rest of the still-living body, often by dumping it back into the ocean.The body's sharks without fins are often thrown back into the ocean alive, where they are die because unable to swim properly and bleeding profusely or die of blood loss. Shark fins are tempting targets for fishermen because they have high monetary and cultural value. Fins are used in a popular dish called shark fin soup, which is a symbol of status. This review will provide a description of definition of shark finning, shark fin soup, dengerous delicacy for humans and sharks alike and aim to protect shark population.

Keywords : Indonesian's ocean ; Save our shark ; Shark Finning ; Shark fin soup.

\section{PENDAHULUAN}

Dalam perkembanganya, fenomena kerusakan lingkungan yang marak diberitakan menjadi salah satu fokus perhatian masyarakat internasional pada masa ini. Isu hangat yang tidak kalah penting adalah mengenai perburuan sirip hiu yang semakin merajalela di seluruh belahan dunia dimana dari data yang diperoleh, Indonesia termasuk kedalam negara pertama dalam pembantaian hiu dengan China dan Hongkong sebagai 
negara pengimpor hiu utama untuk dikonsumsi sebagai sup sirip hiu yang merupakan kebudayaan mereka. White et al., (2006) melaporkan di Indonesia terdapat sekitar $137 \quad$ spesies Elasmobranchii yang terdiri atas 78 jenis hiu, 56 jenis pari dan 3 jenis Chimaera (hiu hantu) di perairan Indonesia.

Tingginya permintaan pasar ikan hiu menjadikan angka perburuan ikan hiu semakin meningkat. Permintaan sirip hiu bukan hanya untuk pasar domestik tetapi juga konsumen internasional seperti Cina dan Hawai. Berdasarkan data dari lembaga pemantauan satwa liar selama 2002-2011 indosesia merupakan negara terbesar yang melakukan penangkapan hiu dengan nilai $80 \%$ dari total penangkapan hiu (wwf.or.id, 24/5/2019. 11:00).

Shark Finning adalah memotong sirip hiu yang telah ditangkap secara hiduphidup, lalu hiu tanpa sirip tersebut dibuang ke laut dalam keadaan masih bernyawa. Bagian sirip diipotong dan bagian tubuh lainnya dibuang. untuk kemudian mati secara perlahan karena pendarahan dan tidak bisa berenang (Gambar 1). Praktik pembunuhan hiu ini dilakukan terhadap 38 juta hiu setiap tahunnya (Clarke et al., 2006) sebanyak 26-73 juta hiu yang tertangkap dalam aktivitas perikanan dunia (Fordham et al., 2010).

Kondisi ini membuat sekitar 1-2 individu hiu tertangkap setiap detiknya. Adanya peluang pasar yang besar terhadap bagian sirip hiu membuat spesies ini terancam punah.

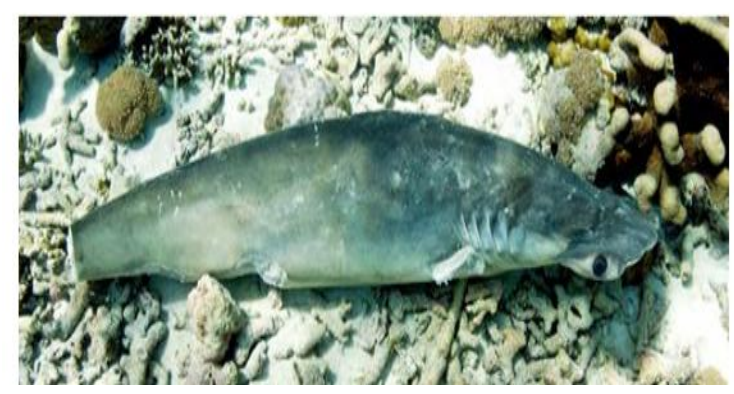

Gambar 1. Praktik Shark Finning
Rendahnya pemahaman masyarakat tentang dampak penangkapan mengkonsumsi sup sirip hiu membuat praktik ini masih marak dilakukan dimasyarakat disamping itu kurangnya tingkat kepedulian dan minimnya peraturan terhadap konversi ikan hiu. Membuat penangkapan ikan hiu masih dilakukan demi memenuhi kebutuhan pasar.

Berdasarkan fenomena yang telah diuraikan diatas. Pada direview ini akan dibahas mengenai pentingnya pemahaman tentang dampak yang ditimbulkan dari mengkonsumsi sup sirip hiu dan cara mengurangi praktek ini.

\section{WILAYAH PENANGKAPAN HIU DI PERAIRAN INDONESIA}

Aktivitas penangkapan ikan hiu meningkat akibat adanya peluang pasar baik dalam maupun luar negri. Salah satu jenis hiu yang ditangkap di perairan Indonesia adalah Alopias pelagicus, Alopias superciliosus, Carcharhunus falcifomis dan Sphyrna lewini.

Alopias palagius merupakan jenis hiu dalam appendix II CITIES. Hiu jenis ini hidup dipermukaan hingga kedalaman 152 $\mathrm{m}$. Jenis hiu ini banyak diterdapat diperairan Sumatra hingga Nusa Tenggara, Laut Pasifik, Selat Makasar, dan Laut Sulawesi. Panjang hiu ini mencapai 109$325 \mathrm{~cm}$ (White et al, 2006).

Alopias superciliosus meripakan salah satu dalam Appendix II CITES. Alopias superciliosus merupakan jenis hiu oseanik yang dihidup dipermukaan hingga kedalaman 600 m. Hiu Alopias superciliosus terdapat diperairan Samudara Hindia mulai dari Sumatra hingga Nusa Tenggara, Laut Banda, Laut Sulawesi, Selat Makasar dan Laut pasifik. Ukuran hiu ini berkisar antara 280-330 (Frose \& pauly, 2017).

Carcharhinus falcifomis merupakan jenis hiu dalam Appendix II CITES. Carcharhinus falcifomis merupakan jenis hiu osenaik yang dihup dikedalam $500 \mathrm{~m}$. 
Jenis Carcharhinus falcifomis terdapat pada periaran samudra hindia, Sumatra hingga Nusa Tenggara, Laut Cina Selatan, Selat makasar dan laut jawa. Ukuran hiu ini berkisar antara 62-254 (Dahramadi et al., 2013).

Sphyrna lewini merupakan salah satu hui dalam Appendix II CITES. Hiu ini Sphyrna lewini ditemukan di perairan tropis seperti Samudra Hindia, Selat Sunda, Laut Jawa, Laut Cina Selatan, serta perairan Sumatra, Kalimantan, Sulawesi, Maluku dan Papua. Ukuran hiu ini berkisar antara 370-420 (Fahmi \& Dharmadi, 2013; White et al., 2006).

Pelabuhan Perikanan Nusantara (PPN) mencatat penangkapan hiu pada tahun 2004 memiliki data seperti Tabel 1.

Tabel 1. Jenis Hiu di Pelabuhan Ratu

\begin{tabular}{ll}
\hline Jenis Hiu & $\begin{array}{l}\text { Produksi } \\
(\mathrm{kg})\end{array}$ \\
\hline Isurus oxyrinchus & 1.682 \\
Carcharhinus amblyrhnchos & 16.710 \\
Carcharhinus plumbeus & 327 \\
Sphyrna lewini & 2.323 \\
Carcharhnius brachyurus & 885 \\
Carcharhius longimanus & 847 \\
Prionace glaucu & 25.229 \\
Carcharhinus melanopterus & 32.506 \\
Alopias superciliosus & 2.023 \\
Galeocerdo cuvieri & 1.201 \\
Alopias Pelagius & 3.588 \\
\hline Total & 87.296 \\
\hline
\end{tabular}

Statistic : (PPN, 2004)

Penangkapan hiu cukup tinggi tinggi di Indonesia. Salah satu tempat yang mendata penangkapan hiu di Indonesia terdapat di Pelabuhan Ratu. Pelabuhan Ratu ditetepkan menjadiDi Indonesia terdapat 2 metode penangkapan hiu yang umumnya digunakan yaitu jaring Liong Bun (Gillnet Cucut) dan unit panangkapan Rawai Cucut.

Metode penangkapan jaring Liong Bun (Gillnet Cucut) adalah metode penangkapan dengan cara jaring direntangkan dekat dasar perairan dengan bantuan jangkar sebanyak 100 piece per kapal lalu pada bagian ujung diberikan pelampung pada permukaan. Terdapat 10 orang dalam penangkapan ini. 1 orang sebagai tekong penanggung jawab kapan melakukan setting dan kapan harus melakukan hauling / penarikan, 1 yang bertugas menjaga kestabilan mesin dan 8 orang sisanya yang melakukan setting dan hauling (Fauziyah, 1997).

Rawai cucut merupakan teknik mengakap dengan menggunakan tali. Terdapat 6 jenis tali yang digunakan yaitu tali pelampung, tali utama, mata pancing , tali cabang, pelampung dan tiang bendera (Rahyuningsih, 1993). Terdapat 7 orang dalam penangkapan ini. Satu orang sebagai juru mudi yang bertugas bertanggung jawab terhadap oprasi penangkapan dan wilayah penangkapan. Sedangakan 7 oarang lainnya sebagai penangkap hiu pada posisi setting, hauling dan penanganan hasil tangkapan (Rahyuningsih, 1993).

Ketertarikan hiu terhadap darah dimanfaatkan dalam proses penangkapan hiu. Darah hewan yang digunakan dalam penangkapan meliputi darah cakalang, lemendang dan lumba-lumba (Hendrotomo, 1989), sapi (Narsongko,1993), layur, cucut, remang, sidat, belut laut (Wirianata, 1982).

\section{ANALISA DAMPAK SHARK FINNING TERHADAP KEHIDUPAN LAUT}

Penangkapan ikan hiu meningkat pada beberapa tahun terakhir. Berdasarkan data dari Food and Agricultural Organization / FAO jumlah penangkapan hiu pada tahun 2008 sebesar 109.248 ton dan meningkat pada tahun 2010 sebesar 113.626 ton (Lack and Sant, 2011). Bila kondisi ini berlangsung dalam waktu yang lama maka dapat menggangu keseimbangan kehidupan laut.

Hiu adalah ikan dengan reproduksi dan perkembangbiakannya yang rendah 
dengan menghasilkan sedikit anakan (dengan masa mengadung 1-2 tahun), hanya berkembangbiak setiap 1 hingga 3 tahun sehingga rentan terhadap eksploitasi berlebih sementara permintaan terus meningkat sebesar $5-15 \%$ dan menyebabkan beberapa populasi hiu di Atlantik telah menurun sebesar 90\% selama 15 tahun terakhir.

Hiu merupakan ikan yang dapat mengkontrol populasi hewan laut dalam rantai makanan Hal ini dikarenakan hiu merupakan predator teratas yang dapat memangsa hewan yang terluka/sakit dan hewan dalam kondisi lemah sehingga bisa membersihkan laut. Adanya populasi hiu juga dapat mengkontrol populasi hewan laut dalam rantai makanan, menjaga ekosistem laut serta menjaga kelimpahan ikan-ikan, dan memastikan kesehatan ekosistem laut terjaga. Namun jika eksploitasi terhadap hiu terus terjadi maka keseimbangan ekosistem akan terancam dan dapat berdampak buruk pada ketahanan pangan/sumber protein di wilayah perairan Indonesia.

Di Atlantik, penurunan 11 jenis populasi hiu mengakibatkan meningkatnya 12 jenis populasi ikan pari hingga 10 kali lipat. Ikan pari merupakan pemangsa jenis kerang-kerangan (bivalvia). Meningkatnya populasi ikan pari menyebabkan penurunan bivalvia. Hilangnya bivalvia meningkatkan tingkat kekeruhan air. Peningkatkan tingkat kekeruahan air menyebabkan tingkat kemampuan fotosintesis lamun menurun. Penurunan jumlah lamun menyebabkan ikan-ikan juga hilang atau tidak bertahan hidup, hingga kawasan itu disebut dead zone.

Ancaman lain yang di hadapi dari penangkapan hiu adalah matinya tangkapan sampingan. Tangkapan sampingan adalah spesies lain yang ikut tertangkap saat pengkapan hiu. Tangkapan sampingan dapat berupa ikan kecil, lumbalumba, penyu dan burung laut. Tangkapan sampingan tidak bisa dibawa ke daratan sesuai dengan peraturan yang ada sehingga tangkpan sampingan akan dibuang ke laut dengan keadaan masih dihudup, sudah mati atau sedang sekarat (Awere Shark Conservation, 2012).

\section{TRADISI MENGKONSUMSI SUP SIRIP HIU DI CHINA DAN HAWAI}

Di Cina terdapat tradisi mengkonsumsi sup sirip hiu. Sup sirip hiu adalah makanan bercitarasa lezat yang merupakan simbol kemakmuran, kehormatan dan nasib baik. Sup sirip hiu adalah bagian dari makanan etnis Cina. Hidangan ini memiliki harga yang cukup mahal dan tersaji di acara penting seperti jamuan pernikahan, imlek, dan jamuan makan perusahaan.

Sirip hiu adalah produk perikanan termahal didunia tergantung pada spesiesnya, Harga semangkuk sup sirip hiu seharga US\$100. Sirip hiu memberikan tekstur khas dengan kaldu ayam sebagai citarasa dasar untuk sup sirip hiu. Praktik ini dimanfaatkan oleh para nelayan yang membutuhkan pendapatan untuk melangsungkan kehidupannya. Kurangnya perhatian pemerintah dan akses masyarakat di pesisir seperti nelayan dalam pendidikan, lapangan pekerjaan dan akses publik lainnya menyebabkan mereka tidak memiliki pilihan lain selain memanfaatkan peluang praktis yang menguntungkan ini. Ketidakadilan yang dirasakan oleh nelayan ini menyebabkan ketidakadilan pula bagi hiu dan ekologi laut yang mendapatkan dampak buruknya

Bagian sirip hiu bernilai tinggi. Namun Bagian lain dari hiu yang berupa daging hiu kurang bernilai secara ekonomis dibandingkan dari spesies ikan lain yang lebih banyak dimakan, seperti tuna dan ikan pedang. Daging hiu lebih sulit diproses daripada daging dari sebagian besar spesies ikan karena kandungan urea yang tinggi. Harga daging hiu mencapai US\$ 1 hingga US\$1. Bagian kulit dan minyak hati hiu dapat digunakan sebagai obat-obatan dan souvenir. 
Salah satu contohnya adalah : Hiu sirip pendek (hiu porbeagle) dianggap sebagai spesies bernilai tinggi untuk daging di pasar makanan laut Eropa dan AS dan untuk sashimi di Asia. Beberapa spesies hiu, seperti hiu biru dan martil, ditargetkan secara khusus untuk bagaian sirip saja. Kulit hiu dapat dimasak dan dijadikan barang-barang kerjainan tangan seperti tas, dompet, sepatu, jaket dan ikat pinggang oleh industri kecil

Di Hawai beberapa hiu disembah sebagai roh berpengaruh yang penting bagi wilayah geografis, atau keluarga tertentu. Warga Hawai juga percaya bahwa kerabat yang telah meninggal dapat bereinkarnasi dalam bentuk hiu Aumakua . Hiu Aumakua menjadi roh pelindung wialyah geografis yang bermanfaat dan pelindung keluarga (Emerson 1892; Beckwith 1917). Dalam banyak kasus, hiu disembah oleh orang-orang tertentu yang disebut kahu (penjaga) (Emerson 1892; Titcomb dan Pukui 1972).

\section{CARA MENCEGAH PENANGKAPAN HIU}

Proses pemotongan sirip hiu/shrak finning jika dalam waktu yang lama biota laut akan banyak yang rusak, keanekaragaman hayati juga akan hilang seiring dengan banyaknya jumlah hiu yang mati karena ekploitasi. Sebuah kenyataan yang sangat keji saat pelayan indonesia mengatasnamakan uang demi memenuhi pola konsumsi masyarakat cina dalam mengonsumsi sup hiu disisi lain makhluk hidup ikan hiu mengalami eksploitasi akibat ulah kita. Berdasarakan data dari IUCN (International Union for the Conservation of Nature / Uni Internasional untuk Konservasi alam sepertiga hiu atau pari palagis terancam punah, populasi hiu kepala martil berkurang $89 \%$ di wilayah atlantik barat laut dan barat tengah dan 14 spesies hiu terncam punah.

Indonesia sendiri telah memiliki undang-undang nasional tentang perlindungan hiu yang disesuaikan dengan hukum internasional seperti IUCN dimana terdapat 12 jenis hiu dalam daftar Appendix 1, 2, dan 3. Spesies di Appendix 1 secara umum dilarang diperdagangkan karena sedang terancam punah, sementara, Appendix 2 mengatur pengelolaan spesies yang menuju ancaman punah melalui aturan perdagangan yang ketat, sedangkan Appendix 3 mengatur perlindungan spesies setidaknya di satu negara anggota CITES. Bagi Indonesia, upaya perlindungan hiu menjadi kewajiban karena Indonesia telah meratifikasi CITES melalui Kepres No 43 tahun 1978, hanya saja peraturan ini kembali melemah karena tidak ada undang-undang yang secara khusus mengatur jenis eksploitasi hiu. Jika kondisi seperti ini terus terjadi secara berkala maka para pelaku kejahatan yang telah mengeksploitasi hiu terus berkeliaran bebas dan tidak mendapatkan efek jera. Untuk menangaini kondisi ini perlu diadakan gerakan save our shark dilakukan dengan mempromosikan nilainilai baik (promoting virtue) yang berusaha untuk kembali membawa dan menerapkan nilai dan kearifan lokal dalam yang benar serta menggunakan teknologi penangkapan yang tidak merusak ekosistem laut seperti yang dilakukan oleh para masyarakat dahulu. Nilai-nilai kearifan lokal tersebut dimodifikasi sedemikian rupa agar dapat menyesuaikan dengan perkembangan global namun masih memperhatikan kelangsungan lingkungan

\section{KESIMPULAN}

Praktik shark Finning (memotong sirip hiu) di Indonesia meningkat setiap tahun. Peningkatan ini dikarenakan tingginya tingkat permintaan akan sirip hiu di cina. 
Sirip hiu di Cina dijadikan sebagai hidangan kemakmuran, kehormatan dan nasib baik. Penangakapan hiu ini menyebabkan ketidakseimbangan ekosistem laut. adanya kampanye untuk melindungi hiu seperti SOS/ save our shark/ Dead zone untuk melindungi dan membatasi penangakapan hiu. Namun penangkapan hiu ini mulai dibatasi dengan adanya hukum IUCN dan memelihara kelestarian lingkungan sehingga dapat menciptakan keadilan baik bagi manusia maupun lingkungan (hiu). Salah contohnya adalah dengan memberikan edukasi mengenai cara penangkapan hiu yang benar dan pembuangan limbah hiu.

\section{DAFTAR PUSTAKA}

Apa D. A. Chad S. M. and Kaneshiro-P. M. Y. (2014). The Influence of Culture on the International Management of Shark Finning. Environmental Management, 54(2), 151-161. doi:10.1007/s00267-014-0291-1

Baum, J. K. (2003). Collapse and Conservation of Shark Populations in the Northwest Atlantic. Science, 299(5605), 389-392. doi:10.1126/science.1079777

Clarke SC, Milner-Gulland EJ, Cemare TB. (2007). Perspective, Social, Economic, and Regulatory Drivers of the Shark Fin Trade. Marine Resource Economics. 22:305-327.

Clarke, S. C., McAllister, M. K., MilnerGulland, E. J., Kirkwood, G. P., Michielsens, C. G. J., Agnew, D. J., Shivji, M. S. (2006). Global estimates of shark catches using trade records from commercial markets. Ecology Letters, 9(10), 1115-1126. doi:10.1111/j.1461-0248.2006.00968.

Derian D., Cahyo D. F., (2017). Status Peredaran Produk Jenis Hiu di Indonesia.

Geoffrey York (2003-08-27). "Shark Soup" (http:/ / www. flmnh. ufl. edu/ FISH/ sharks/ innews/ sharksoup2003. htm). The Globe and Mail.. Retrieved 8 January 2007"shark conservation" (http:/ / www. bluespheremedia. com/ shark-conservation. html). Blue Sphere Media. . Retrieved 5 December 2007.

Jaiteh V.F. Hordyk R. A., Braccini M., Warren C., Lonerangan N., (2017), Shark Finning in Estern Indonesia : Assessing the Sustainability of Data-Fishery., ICES Journal of Marine Science 74: 247-253.

Maguire, J.-J.; Sissenwine, M.; Csirke, J.; Grainger, R.; Garcia, S.(2006) The State of World Highly Migratory, Straddling and Other High Seas Fishery Resourcesand Associated Species. FAO Fisheries Technical Paper. No. 495. Rome: FAO. 84p.

Munadi Adi.,(2006), Analisis Sekreasi Untuk Tujuan Pengumpulan Ikan Hiu dalam Penangkapan ikan. Skripsi. Fakultas Parikanan dan Ilmu kelautan. IPB. Bogor.

Nur kumlasari, (2012) , Global Justice Movement: "Save Our Shark" oleh Shark Angel. Ecology letters .

Santoso A. A. (2017). Karakteristik Biologi Hiu dan Pari Appendiks II CITES yang didaratkan di Tanjung Luar, Lombok Timur. Seminar Nasional Tahunan XIV.

Sudjoko B. 1991. Pemanfaatn Ikan Cucut. Osean, Vol. XVI no. (4): 31-37.

White, W.T., P.R. Last., J.D. Stevens, G.K. Yearsley, Fahmi \& Dharmadi. (2006). Economically important sharks and rays of Indonesia (Hiu dan pari yang bernilai ekonomis penting di Indonesia). ACIAR Monograph Series; no. 124. Australian Centre for International Agricultural Research, Canberra. 329 pp. 